\title{
Genomic Stability of Palmer amaranth Plants Derived by Macro-Vegetative Propagation
}

\author{
Neal Dwaine Teaster, Robert Edward Hoagland* \\ US Department of Agriculture-Agricultural Research Service, Crop Production Systems Research Unit, \\ Stoneville, USA \\ Email: ${ }^{*}$ bob.hoagland@ars.usda.gov
}

Received 15 August 2014; revised 21 September 2014; accepted 21 October 2014

Copyright (C) 2014 by authors and Scientific Research Publishing Inc.

This work is licensed under the Creative Commons Attribution International License (CC BY). http://creativecommons.org/licenses/by/4.0/

cC) (i) Open Access

\begin{abstract}
qPCR (quantitative polymerase chain reaction) and random amplified polymorphic DNA (RAPD) were utilized to investigate genetic stability of Palmer amaranth cloned plants over 10 generations. DNA from original parent Palmer amaranth plants (grown from seeds) was re-analyzed using $\mathrm{qPCR}$, and confidence levels for determining $\Delta \Delta \mathrm{Ct}$ (threshold crossing) values were established. ANOVA was used to determine variation (margin of error) of these $\Delta \Delta \mathrm{Ct}$ values. This margin of error was applied to qPCR analysis of DNA from eight individual parent plants and their descendants $\left(10^{\text {th }}\right.$ generation) so that possible differences in EPSPS (5-enolpyruvylshikimate-3phosphate synthase) gene copy number could be ascertained. This method (and the associated error) indicated a lack of agreement in $\Delta \Delta$ Ct values of DNA from plants of these two generations. qPCR analysis showed that in five out of eight clones, EPSPS gene copy number varied more than the calculated error $(P=0.05)$. A second technique to monitor genetic stability, RAPD was used to determine possible changes in genomic DNA due to extended cloning of these regenerated plants. RAPD analysis showed that four out of the eight clones differed when the profiles of the two generations were compared. Results show that QPCR and RAPD analysis point to the fact that several Palmer amaranth clones experienced changes in genome structure over 10 generations. Although the glyphosate resistance trait was retained, results suggest that during cloning studies, the genetic stability of macro-vegetatively propagated lines should be monitored.
\end{abstract}

\section{Keywords}

Amaranthus palmeri, EPSPS, Gene Copy Number, Glyphosate-Resistant Weeds, Palmer amaranth, Pigweed, qPCR, RAPD

\footnotetext{
*Corresponding author.
} 


\section{Introduction}

Weeds have an estimated potential to cause nearly a 35\% loss in crop yield when six crops were examined on a worldwide basis [1]. World pesticide expenditures exceeded \$35 billion in 2007, with herbicides totaling over $40 \%$ (\$14 billion) and herbicide sales in the US totaled nearly \$5 billion in 2007 [2]. There are other obvious additional economic factors associated with weeds including, herbicide application costs and crop yield losses due to competition and contamination. Annual costs (damage and control costs) associated with alien plant species introduced into the US has been estimated at \$34 billion [3].

An additional facet of weed control or weed management is the development of herbicide resistance. Currently, 238 species of weeds have become resistant to various herbicides in 65 countries, with 30 weeds documented as resistant to glyphosate [ $N$-(phosphonomethyl)glycine] [4]. Glyphosate use in glyphosate-resistant (GR) crops to control weeds has exacerbated the development of weed resistance to this herbicide [5].

Palmer amaranth (Amaranthus palmeri S. Wats.), a dioecious plant (either male or female), has a rapid growth rate [6], can attain a height of $2 \mathrm{~m}$ or more [7] and produces numerous seeds [8] [9]. In addition to its weedy traits, Palmer amaranth has become a major glyphosate-resistant weed in the southeastern United States [10] and some biotypes possess resistance to other herbicides including: PS II inhibitors (triazine), acetolactate-synthase inhibitors, and dinitroanilines, and HPPD inhibitors [4] [11]-[15]. These growth and reproductive traits coupled with the tendency to develop resistance to herbicides make it extremely competitive and difficult to control.

Wide genetic variability within a weed population can lead to the selection of a resistant individual when the population is under high selection pressure (for example, repeated applications of the same herbicide). As a result, resistant plants in a field can dominate a population in only four to five generations (years) [16]. Glyphosate-resistance in Palmer amaranth (Amaranthus palmeri) was first reported in Georgia [17] and soon following this event, glyphosate resistant Palmer amaranth was discovered in several other southern states [18] [19]. Glyphosate-resistant Palmer amaranth is now widespread in the southern US where it has been cited as one of the most troublesome weeds of agronomic crops [20].

Multiple factors are involved in the distribution of Palmer amaranth, including the spread of seeds by equipment, animals, wind and water. Resistance traits can be spread through pollen (genetic exchange), and since Palmer amaranth is an obligate out-crosser (cross-pollinator), exchange of genetic traits can proceed rapidly. Pollen can travel up to 1000 feet from a resistant male plant to susceptible female plants [21]. Some populations of Palmer amaranth contain multiple copies (5 to 160) of the EPSPS (5-enolpyruvylshikimate-3-phosphate synthase) gene, which was originally reported as the mechanism of resistance to glyphosate [22]. This resistance trait has also been found in other biotypes of this species [23]-[26].

Studies of populations of a given weed versus analysis of individual plants when addressing mechanism of resistance or other certain physiological, biochemical and molecular biological questions pose an important issue. In Palmer amaranth, results have indicated a wide range or variation in resistance in biotype populations and wide diversity of individuals within populations of this weed [27]. A macro-vegetative propagation method was used to facilitate long-term study on selected cloned lines of this weed so that in-depth examination of individual plants could be achieved [26]. RAPD (random amplified polymorphic DNA) has proven to be an efficient method to detect genetic variations [28] [29] and RAPD markers have been successfully applied to detect the genetic similarities or dissimilarities in micro-propagated material in various plants [30]. Quantitative polymerase chain reaction (qPCR) is another technique used to amplify and quantify a specific RNA/DNA sequence. qPCR enables both detection and quantification of one or more specific sequences in an RNA/DNA sample. Quantification can provide an absolute number of RNA/DNA sequence copies or a relative amount of copies when normalized to RNA/DNA input or additional normalizing genes [31]. This technique has been useful to determine gene copy number in various studies of herbicide resistant Palmer [22] [26].

Due to the increasing spread and economic cost associated with the spread of glyphosate-resistance Palmer amaranth more biochemical, physiological and molecular biological studies related to growth and reproduction, mechanisms of herbicide resistance and methods of controlling this weed are important. Knowledge gained through these studies will lead to more effective control of this serious weed problem. Continued propagation of selected cloned plant lines can provide genetically characterized individual plant material to carry out such studies. The objectives of this study were to use qPCR and RAPD techniques to examine the genomic stability of individual Palmer amaranth plants descended via macro-vegetative propagation (cloning) over 10 generations from parents previously characterized to have a range of tolerance or resistance to glyphosate [26]. 


\section{Materials and Methods}

\subsection{Plant Growth and Culture}

Seeds of the Palmer amaranth source were planted in a commercial potting mix Jiffy-mix (Jiffy Products of America, Inc., USA) contained in plastic trays $(12 \mathrm{~cm}$ by $12 \mathrm{~cm})$. These trays were placed into larger sub-irrigated trays placed on greenhouse benches. Greenhouse temperatures ranged from $28^{\circ} \mathrm{C}$ to $32^{\circ} \mathrm{C}$ with $40 \%-90 \%$ relative humidity (RH). The photoperiod was $12-14 \mathrm{~h}$ with $1650 \mu \mathrm{Em}^{-2} \cdot \mathrm{s}^{-1}$ photosynthetically active radiation measured at midday with a light meter (LI-COR, Inc., USA). The plants were thinned about one week after emergence (6 - 8 per tray) and the young seedlings were supplied with NPK (Miracle-Gro; The Scotts Company LLC, USA) on a weekly cycle. Two weeks after emergence, plants were selected and transplanted into large plastic pots (160 mm diam.) containing the soil mixture as described above and grown to the appropriate stage as needed for testing.

\subsection{Plant Macro-Vegetative Propagation (Cloning)}

To test and characterize individuals from this population in a variety of tests over a long time period, selected individual parent plants (grown from seeds) were cloned as described elsewhere [26]. Parent plants and their successive cloned lines used in the present study were previously named using an alpha-numeric code (R-5, R-6, R-7, R-9, G-1, G-3, G-4, G-8). Briefly, excised petioles from branch points ( 10 - 20 mm long) of mature plants were immediately placed in deionized water. Each excised plantlet was removed from the water, blotted (absorbent paper towels), the cut end coated with rooting hormone powder (Hormex; 1.6\%) (Brooker Chemicals, USA), and planted in moistened vermiculite/peat/loam mixture contained in plastic trays $(6 \mathrm{~cm} \times 14 \mathrm{~cm})$. The planted cuttings ( 8 to 10 plantlets per tray) were maintained at $21^{\circ} \mathrm{C}-23^{\circ} \mathrm{C}$ under low continuous light ( 150 $\left.\mu \mathrm{Em}^{-2} \cdot \mathrm{s}^{-1}\right)$ for 6 to 7 days to allow root initiation and growth, and then transferred to a greenhouse $\left(28^{\circ} \mathrm{C}\right.$ $34^{\circ} \mathrm{C}$, a $14 / 10$ day/night cycle at $\sim 1650 \mu \mathrm{Em}^{-2} \cdot \mathrm{s}^{-1}$ during the day) or growth chamber at similar environmental conditions. Plants propagated by this method were grown to the desired growth stage, re-cloned and/or used for testing.

\subsection{DNA Extraction and qPCR}

DNA was isolated from fresh leaves of Palmer amaranth according to a modified method of the DNeasy Plant Mini Kit (QIAGEN Inc., USA), quantified spectrophotometrically by means of a Nano Drop ${ }^{\mathrm{TM}}$ 2000C and analyzed for quality (lack of fragmentation or degradation) using gel-electrophoresis. qPCR was conducted using Power Syber-Green Master Mix (Applied Biosystems, USA) on an ABI-7500 Real Time PCR System (Applied Biosystems, USA). The qPCR thermocycler program consisted of an initial $5 \mathrm{~min}$ at $94^{\circ} \mathrm{C}$, followed by 30 cycles of $1 \mathrm{~min}$ at $94^{\circ} \mathrm{C}, 1 \mathrm{~min}$ at $58^{\circ} \mathrm{C}$, and $1 \mathrm{~min}$ at $72^{\circ} \mathrm{C}$, with a final extension of $10 \mathrm{~min}$ at $72^{\circ} \mathrm{C}$. To determine gene copy number of EPSPS, gene specific primers for EPSPS and ALS (acetolactate synthase) were utilized: EPSPSF (5'-CAACAGTTGAGGAAGGATCTG-3', EPSPSR (5'-CAGCAAGAGAGAATGCCAT-3') and ALS, ALSF (5'-GCTGCTGAAGGCTACGCT-3'), ALSR (5'-GCGGGACTGAGTCAAGAAGTG-3') [22] and primer efficiency was determined [31]. $\Delta \Delta \mathrm{Ct}=\left[\left(\mathrm{Ct}_{\mathrm{EPSPS}}-\mathrm{Ct}_{\mathrm{ALS}}\right)\right.$ resistant $\left.-\left(\mathrm{Ct}_{\mathrm{EPSPS}}-\mathrm{Ct}_{\mathrm{ALS}}\right)\right]$ sensitive was determined relative to the low copy number control ALS gene, with known monogenic inheritance in other Amaranthus species [32].

\subsection{RAPD Analysis}

Five arbitrary 10-base primers (Ready-To-Go RAPD Analysis Beads; GE Healthcare, USA) were used for polymerase chain reaction (PCR). Primer sequences were: P1-5'-GGTGCGGGAA-3'; P2-5'-GTTTCGCTCC-3'; P3-5'-GTAGACCCGT-3'; P5-5'-AACGCGCAAC-3'; and P6-5'-CCCGTCAGCA-3'. Amplification reactions were performed with one reaction bead, 50 ng template DNA, and 25 pmol of the primer, brought to a volume of $25 \mu$ with molecular grade water. Replicate DNA amplification was performed in a PTC-200 Peltier thermal cycler (St. Bruno Quebec, Canada) programmed for 45 cycles as follows: first cycle of 5 min at $95^{\circ} \mathrm{C}, 45$ cycles each of $1 \mathrm{~min}$ at $95^{\circ} \mathrm{C}, 1 \mathrm{~min}$ at $36^{\circ} \mathrm{C}, 2 \mathrm{~min}$ at $72^{\circ} \mathrm{C}$. The amplification products were separated by electrophoresis in $2 \%(\mathrm{w} / \mathrm{v})$ agarose gel with $0.5 \times$ TAE buffer and stained with fluorescent DNA dye (AMRESCO EZ-vision; AMRESCO, USA). 


\subsection{Amplified DNA Marker Scoring}

Electrophoretic gel images were captured with Bio-Rad Image Lab software version 4.1 build 16 and evaluated for presence and size utilizing Carestream Molecular Imaging Software, 5.0 2.30. Amplified DNA band profiles on gels were scored as present or absent for each macro-propagated plant. DNA bands of low visual intensity (not readily discernible) were considered as ambiguous markers and were not scored. The data were analyzed using locus-to-locus gel readings and the rates of in vitro DNA polymorphism were determined and presented as number of bands in agarose gels for each clone.

\subsection{Statistical Analysis}

Analysis of variance (ANOVA) was performed using SAS Statistical Software to determine if current generation relative $\Delta \Delta \mathrm{Ct}$ was different from parent generation relative $\Delta \Delta \mathrm{Ct}$. ANOVA was performed using a general linear mixed model with fixed effects for: generation (parent vs current), type (resistant vs susceptible), clone within type (8 resistant clones plus 2 susceptible clones), generation $\times$ type and clone $\times$ generation within type. Random effects estimate sources of variability in data with Rep (random block effect representing differences in parent data between stored DNA and DNA at time of extraction), Rep ${ }^{*}$ generation and residual error (3 technical measurements on each sample). Least Significant Differences (LSD) at $\mathrm{P} \leq 0.05$ were calculated and used to compare: 1) Ct difference between each resistant clone and susceptible clone (C3-9); 2) Ct difference between each resistant clone and susceptible clone (C3-7); and 3) $\mathrm{Ct}$ difference between each resistant clone and the mean of susceptible clones (C3-9 and C3-7).

\section{Results and Discussion}

In our investigations of glyphosate resistance in Palmer amaranth plants of resistant and susceptible populations, plants grown from seed were tested using whole plant spraying (destructive) and leaf disc bioassay (nondestructive) techniques [27] [33]. Selected plants were then chosen for macro-vegetative propagation (cloning) [26] to retain consistent genetic lines of these individuals for extensive investigations. This method has enabled the maintenance of many genetically distinct lines of Palmer amaranth asexually, without introduction of new diverse genetic material experienced when plants cross-breed. Palmer amaranth can self-cross or cross with similar species [34] [32], thus altering the genome each generation. The mechanism of glyphosate resistance we are primarily investigating is increased EPSPS gene copy number [22] and an important technique to estimate increased gene copy number is by qPCR.

The present study utilized qPCR and RAPD analysis to examine the genetic stability of successively cloned palmer amaranth plants. To determine the error within the qPCR method, duplicate assays were compared. Genomic DNA from the parent of each of the eight lines cloned was initially analyzed at extraction time, and a second test performed on the same extract (stored $-80^{\circ} \mathrm{C}$ ) one year later (Figure 1). The average difference in $\Delta \Delta \mathrm{Ct}$ values between the fresh and stored parent DNA was $0.235 \pm 0.042 \mathrm{SEM}$. Changes in $\Delta \Delta \mathrm{Ct}$ values outside of this error were arbitrarily considered to reflect real changes in the EPSPS gene copy number when applied to other qPCR analyses comparing cloned plants tissue to that of their respective parents.

ANOVA was used to estimate the $\Delta \Delta$ Ct values (determined by qPCR) of each $10^{\text {th }}$ generation Palmer amaranth plant relative to its parent. Table 1 depicts the $\Delta \Delta \mathrm{Ct}$ of the $10^{\text {th }}$ generation minus the $\Delta \Delta \mathrm{Ct}$ of the parent generation. $\mathrm{P}$ is the percent or probability of being wrong at the rejection of the null hypothesis: parent generation $\Delta \Delta \mathrm{Ct}$ value EPSPS gene is equal to $\Delta \Delta \mathrm{Ct}$ value EPSPS gene of the new generation. qPCR results comparing the parent to the $10^{\text {th }}$ generation clone indicated that 5 out of eight clones had a significantly different EPSPS gene copy number (Table 1). qPCR has been used to demonstrate that elevated EPSPS gene copy number in Palmer amaranth populations confers resistance to glyphosate [22]. However, due to the exceptionally high copy number found in this weed $(>100)$, even a small error in $\Delta \Delta \mathrm{Ct}$ can greatly skew the gene copy number value. It has been suggested that generally between 30 - 50 EPSPS gene copy numbers are required for a plant to survive typical field rates of glyphosate [35]. All plants used in the present study had copy numbers greater than this value range and they all (parent plants and $10^{\text {th }}$ generation plants) exhibited resistance to glyphosate. In another study, individual plants with a wide range of EPSPS gene copy numbers within a population exhibited varying degrees of susceptibility to glyphosate which did not always correlate with copy number, suggesting the possibility of other resistance mechanisms [26]. Tests on another population of Palmer amaranth with low EPSPS 


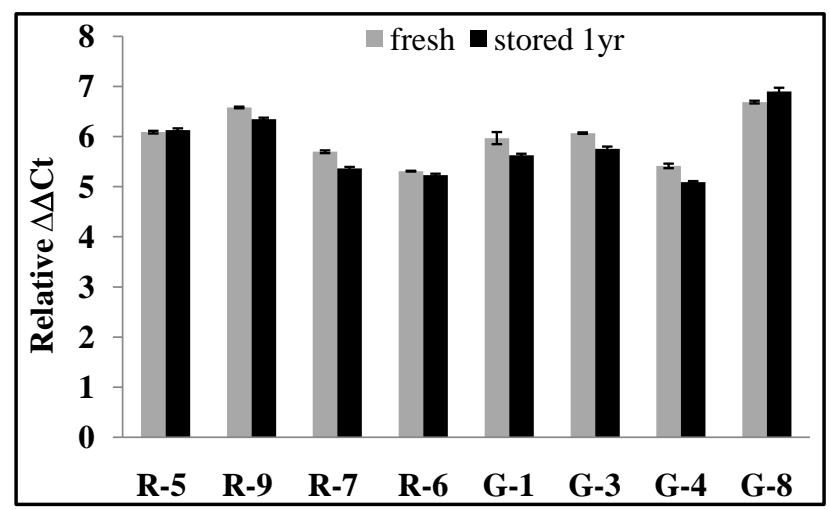

Figure 1. Average difference in qPCR $\Delta \Delta \mathrm{Ct}$ values between fresh and stored original parent DNA. Error bars are \pm 1 SEM.

Table 1. $\Delta \Delta \mathrm{Ct}$ differences between original parent and $10^{\text {th }}$ generation clone. Asterisks indicate clones with altered EPSPS gene copy number.

\begin{tabular}{cccccccccc}
\hline Clone & R-5 $^{*}$ & R-6 & R-7 & R-9 & G-1 & G-3 & G-4 & G-8 $^{*}$ \\
\hline$\Delta \Delta$ Ct & 0.8466 & 0.1334 & 0.4272 & -0.6991 & -0.5719 & -0.6169 & 0.2857 & -0.8466 \\
$\mathrm{P}$ & 0.0068 & 0.5439 & 0.0742 & 0.0092 & 0.0243 & 0.0172 & 0.2099 & 0.0031 \\
\hline
\end{tabular}

gene copy numbers showed that individual plants exhibited a wide degree of susceptibility to glyphosate, also suggesting alternative resistance mechanisms to this herbicide [33].

RAPD analysis is an easy and economical way to evaluate the genetic fidelity of propagated plants. For example, it has been utilized to test genetic stability in prickly pear (Opuntia spp.) [36] and turmeric (Curcuma longa) [37]. In another study, five primers were used to distinguish 13 polymorphisms that occurred across 6 of 23 axillary branching-derived plants from Populus deltoides clones [38]. RAPD markers were useful to evaluate genetic stability of regenerated soybean plants, obtained through somatic embryogenesis [39]. This method has also been utilized to develop markers in Amaranthus species [40].

In the present study, RAPD analysis was used to determine possible genetic variance in Palmer amaranth propagated over ten cloned generations. Five primers produced 34 reproducible and polymorphic banding patterns, and the number of bands produced ranged from 5 - 9 scoreable bands, depending on primer used. Gel images (Figure 2) of RAPD profiles of primers P1, P2, P3 and P5 show the banding patterns of the original parent (O) and $10^{\text {th }}$ generation clone (C). Primer P6 did not show any differences in banding patterns and therefore is not depicted. The presence or absence of a band differing from the parent suggests that the genome has changed during the ten generations covered in this study. A summation of the gel image data is presented in tabular form (Table 2). Changes in the banding pattern indicates some alterations in the genome, however these changes may or may not reflect changes of the EPSPS gene. Table 3 summarizes the results of the qPCR and RAPD analyses for each cloned Palmer amaranth line. When the $10^{\text {th }}$ generation clones were compared to their corresponding original parent, R-5 and G-8 showed changes with both methods, whereas R-5, R-6, R-7 and G-8 showed changes utilizing the RAPD method and R-5, R-9, G-1, G3 and G-8 indicated genomic changes with qPCR. The one exception was the $10^{\text {th }}$ generation clone G-4 which showed no changes using either method. This could be due the fact that no changes occurred, changes occurred but were below the sensitivity of specific qPCR method conditions, or changes may have occurred outside the genomic regions that were analyzed by RAPD.

Modifications of the qPCR method, such as incorporation of gene specific molecular beacons for the target and reference genes, could increase sensitivity (and costs). Greater numbers of primers than included in the RAPD kit would have increased coverage of the genome, thereby increasing the ability to detect genomic alterations and may have resulted in a closer agreement between the QPCR and RAPD results observed in the present study. Nevertheless, the results of this study suggest that some genomic alterations occurred during the 10 generations of cloning in these Palmer amaranths, but not to a degree that compromised resistance to glyphosate. It is possible that during the process of macro-propagation transposon activity or other mechanism(s) may be re- 


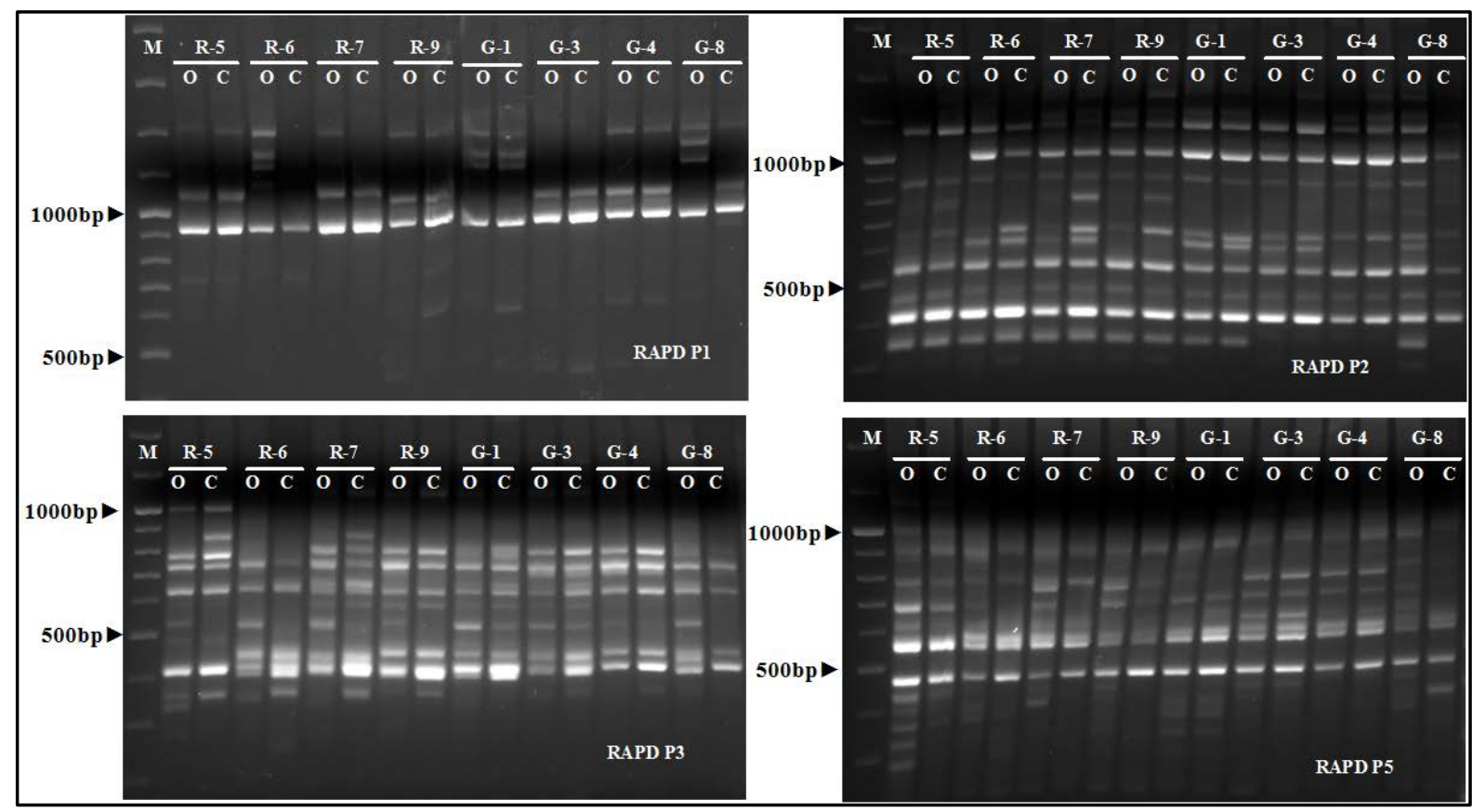

Figure 2. Genetic variation in Palmer amaranth clones relative to parent plants investigated by RAPD analysis. Lane M represents a 100 bp ladder. Clones: R-5, R-6, R-7, R-9, G-1, G-3, G-4, G-8. Original parent = O; Clone = C. RADP primers P1, P2, P3 and P5 are defined in the Methods and Materials.

Table 2. RAPD band pattern comparison of $10^{\text {th }}$ generation clone relative to original parent RAPD band pattern.

\begin{tabular}{|c|c|c|c|c|c|c|c|c|}
\hline & R-5 & R-6 & $\mathrm{R}-7$ & R-9 & G-1 & G-3 & G-4 & G-8 \\
\hline Primer 1 & same & different & same & same & same & same & same & different \\
\hline Primer 2 & same & same & different & same & same & same & same & different \\
\hline Primer 3 & different & different & different & same & same & same & same & different \\
\hline Primer 5 & same & same & different & same & same & same & same & different \\
\hline Primer 6 & same & same & same & same & same & same & same & same \\
\hline
\end{tabular}

RAPD banding profile rating: "same" = no changes in the banding pattern between original parent and $10^{\text {th }}$ generation clone; "different" = band absent or present as a different size.

Table 3. Summary of qPCR and RAPD analysis of changes in genome profile*.

\begin{tabular}{cccc}
\hline Clone line & qPCR & RAPD \\
R-5 & + & + \\
R-6 & + & + \\
R-7 & + & + \\
R-9 & + & + \\
G-1 & & + \\
G-3 & + & + \\
G-4 & & + \\
\hline
\end{tabular}

sponsible for altering EPSPS gene copy number and the genome. Alterations in the banding patterns could arise via transposon activity as suggested to occur in a glyphosate-resistant Palmer amaranth from Georgia, and re- 
search to elucidate this mechanism controlling the DNA-mediated amplification is being pursued [41] [42]. Further investigation will be required to determine the cause of the alteration of the Palmer amaranth genome and to determine the mechanism of EPSPS gene copy increase.

\section{Conclusions}

Overall, the RAPD primers used to examine the genome of 8 cloned lines revealed that 4 of the 8 lines had genomic changes after 10 generations, which suggests that in plant cloning studies, it is prudent to monitor genetic stability of the propagated lines. Cloning by macro-vegetative propagation can be utilized for evaluating plants during long-term studies, and multiple clones can be used to provide replicates in non-lethal or in lethal tests where plants may be sacrificed since back-up cloned plants are available for continued propagation of each cloned line. Long-term micro-propagation has been utilized for conservation and preservation of plant resources under in vitro conditions and to produce numerous plants (clones) with identical genetics. This method has been used to propagate disease-free planting material and has commercial implications [37]. However, some in vitro transfers over long periods can induce somaclonal genetic variations [43]. There are also cases of low frequency somaclonal genetic variations from axillary-branch raised plants, such as Opuntia ficus-indica [36]. However, an axillary-branch technique was found to be a highly reliable and genetically true-to-type method of plant propagation [36].

Some variation occurred in Palmer amaranth after successive cloning over 10 generations and transposon activity may be a possible cause. The fact that some changes occurred in the genetic profiles may be important in characterizing the stability and primal cause(s) involved in the phenomenon of elevated EPSPS gene copy number. While qPCR analysis indicated that 5 of the 8 clone lines underwent changes in the EPSPS gene copy number, the two lines without changes may contain altered copy numbers at levels not detectable due to the $\Delta \mathrm{Ct}$ error associated with the exceptionally high copy number of glyphosate-resistant Palmer amaranth. Also, the clone lines that did not appear to have altered genomes determined by RAPD analysis may contain changes that were not within the DNA sequences amplified by the primers utilized. Nevertheless, both of these methods indicate changes in EPSPS copy number when progeny plants were compared to parent plants. Further studies will be necessary to characterize the nature of the variation in genetic profiles observed in these macro-vegetatively propagated weeds.

\section{Acknowledgements}

We thank R. H. Jordan for technical contributions to this project. The EPSPS primer sequences used in this study were kindly provided by W. T. Molin and A. A. Wright. D. Boykin is thanked for guidance and advice regarding the statistical analysis of these data.

\section{References}

[1] Oerke, E.C. (2006) Crop Losses to Pests. Journal of Agricultural Science, 144, 31-43. http://dx.doi.org/10.1017/S0021859605005708

[2] Fishel, F.M. (2007) Pesticide Use Trends in the US: Global Comparison, Document PI-143. Pesticide Information Office, UF/IFAS Extension. http://edis.ifas.ufl.edu

[3] Pimentel, D., Zuniga, R. and Morrison, D. (2005) Update on the Environmental and Economic Costs Associated with Alien-Invasive Species in the United States. Ecological Economics, 52, 273-288. http://dx.doi.org/10.1016/j.ecolecon.2004.10.002

[4] Heap, I. (2014) International Survey of Herbicide-Resistant Weeds. http://www.weedscience.org/in.asp

[5] Powles, S.B. (2008) Evolved Glyphosate-Resistant Weeds around the World: Lessons to Be Learnt. Pest Management Science, 64, 360-365. http://dx.doi.org/10.1002/ps.1525

[6] Horak, M.J. and Loughin, T.M. (2000) Growth Analysis of Four Amaranthus Species. Weed Science, 48, 347-355. http://dx.doi.org/10.1614/0043-1745(2000)048[0347:GAOFAS]2.0.CO;2

[7] Menges, R.M. (1987) Allelopathic Effects of Palmer Amaranth (Amaranthus palmeri) and Other Plant Residues in Soil. Weed Science, 35, 339-347.

[8] Bensch, M., Horak, J. and Peterson, D. (2003) Interference of Redroot Pigweed (Amaranthus retroflexus), Palmer Amaranth (A. palmeri), and Common Waterhemp (A. rudis) in Soybean. Weed Science, 51, 37-43. 
http://dx.doi.org/10.1614/0043-1745(2003)051[0037:IORPAR]2.0.CO;2

[9] Sellers, A., Smeda, R.J., Johnson, W.G., Kendig, A.J. and Ellersieck, M.R. (2003) Comparative Growth of Six Amaranthus Species in Missouri. Weed Science, 51, 329-333.

[10] Steckel, L.E. (2007) The Dioecious Amaranthus spp.: Here to Stay. Weed Technology, 21, 567-570. http://dx.doi.org/10.1614/WT-06-045.1

[11] Gossett, B.J., Murdock, E.C. and Toler, J.E. (1992) Resistance of Palmer Amaranth (Amaranthus palmeri) to the Dinitroaniline Herbicides. Weed Technology, 6, 587-591.

[12] Horak, M.J. and Peterson, D.E. (1995) Biotypes of Palmer Amaranth (Amaranthus palmeri) and Common Waterhemp (Amaranthus rudis) Are Resistant to Imazethapyr and Thifensulfuron. Weed Technology, 9, 192-195.

[13] Sprague, C.L., Stoller, E.W., Wax, L.M. and Horak, M.J. (1997) Palmer Amaranth (Amaranthus palmeri) and Common Waterhemp (Amaranthus rudis) Resistance to Selected ALS-Inhibiting Herbicides. Weed Science, 45, 192-197.

[14] Vencill, W.K., Grey, T.L., Culpepper, A.S., Gaines T.A. and Westra, P. (2008) Herbicide-Resistance in the Amaranthaceae. Journal of Plant Diseases and Protection, 21, 41-44.

[15] Wise, A.M., Grey, T.L., Prostko, E.P., Vencill, W.K. and Webster, T.M. (2009) Establishing the Geographical Distribution and Level of Acetolactate Synthase Resistance of Palmer Amaranth (Amaranthus palmeri) Accessions in Georgia. Weed Technology, 23, 214-220. http://dx.doi.org/10.1614/WT-08-098.1

[16] Jasieniuk, M., Brulé-Babel, A.L. and Morrison, I.N. (1996) The Evolution and Genetics of Herbicide Resistance in Weeds. Weed Science, 44, 176-193.

[17] Culpepper, S., Grey, T.L., Vencill, W.K., Kichler, J.M., Webster, T.M., Brown, S.M., York, A.C., Davis, J.W. and Hanna, W.W. (2006) Glyphosate-Resistant Palmer Amaranth (Amaranthus palmeri) Confirmed in Georgia. Weed Science, 54, 620-626. http://dx.doi.org/10.1614/WS-06-001R.1

[18] Scott, R.C., Steckel, L.E., Smith, K.L., Mueller, T., Oliver, L.R. and Norsworthy, J. (2007) Glyphosate-Resistant Palmer Amaranth in the Southeastern United States. Proceedings of the Southern Weed Science Society, 60, 22-24.

[19] York, C., Whitaker, J.R., Culpepper, A.S. and Main, C.L. (2007) Glyphosate-Resistant Palmer Amaranth in the Southeastern United States. Proceedings of the Southern Weed Science Society, 60, 225.

[20] Webster, T.M. (2005) Weed Survey-Southern States: Broadleaf Crops Subsection. Proceedings of the Southern Weed Science Society, 58, 291-294.

[21] Sosnoskie, L.M., Webster, T.M., Kichler, J.M., MacRae, A.W., Grey, T.L. and Culpepper, A.S. (2012) Pollen-Mediated Dispersal of Glyphosate-Resistance in Palmer Amaranth under Field Conditions. Weed Science, 60, 366-373. http://dx.doi.org/10.1614/WS-D-11-00151.1

[22] Gaines, T.A., Zhang, W., Wang, D., Bukun, B., Chisholm, S.T., Shaner, D.L., Nissen, S.J., Patzoldt, W.L., Tranel, P.J., Culpepper, S., Grey, T., Webster, T.M., Vencill, W.K., Sammons, R.D., Jiang, J., Preston, C., Leach, J.E. and Westra, P. (2010) Gene Amplification Confers Glyphosate Resistance in Amaranthus palmeri. Proceedings of the National Academy of Sciences of the United States of America, 107, 1029-1034. http://dx.doi.org/10.1073/pnas.0906649107

[23] Ribeiro, D.N., Pan, Z., Duke, S.O., Nandula, V.K., Baldwin, B.S., Shaw, D.R. and Dayan, F.E. (2014) Involvement of Facultative Apomixis in Inheritance of EPSPS Gene Amplification in Glyphosate-Resistant Amaranthus palmeri. Planta, 239, 199-212. http://dx.doi.org/10.1007/s00425-013-1972-3

[24] Chandi, A., Milla-Lewis, S.R., Giacomini, D., Westra, P., Preston, C., Jordan, D.L., York, A.C., Burton, J.D. and Whitaker, J.R. (2012) Inheritance of Evolved Glyphosate Resistance in a North Carolina Palmer Amaranth (Amaranthus palmeri) Biotype. International Journal of Agronomy, 2012, Article ID: 176108. http://dx.doi.org/10.1155/2012/176108

[25] Mohseni-Moghadam, M., Schroeder, J. and Ashigh, J. (2013) Mechanism of Resistance and Inheritance in Glyphosate Resistant Palmer Amaranth (Amaranthus palmeri) Populations from New Mexico, USA. Weed Science, 61, 517-525. http://dx.doi.org/10.1614/WS-D-13-00028.1

[26] Teaster, N.D. and Hoagland, R.E. (2014) Characterization of Glyphosate Resistance in Cloned Amaranthus palmeri Plants. Weed Biology and Management, 14, 1-10. http://dx.doi.org/10.1111/wbm.12024

[27] Hoagland, R.E., Jordan, R.H. and Teaster, N.D. (2013) Bioassay and Characterization of Several Palmer Amaranth (Amaranthus palmeri) Biotypes with Varying Tolerances to Glyphosate. American Journal of Plant Sciences, 4, 10291037. http://dx.doi.org/10.4236/ajps.2013.45127

[28] Williams, J.G.K., Kubelik, A.R., Livak, K.J., Rafalski, J.A. and Tingey, S.V. (1990) DNA Polymorphisms Amplified by Arbitrary Primers Are Useful as Genetic Markers. Nucleic Acids Research, 18, 6531-6535. http://dx.doi.org/10.1093/nar/18.22.6531

[29] Atienzar, F.A. and Awadhesh, N.J. (2006) The Random Amplified Polymorphic DNA (RAPD) Assay and Related Techniques Applied to Genotoxicity and Carcinogenesis Studies: A Critical Review. Mutation Research, 613, 76-102. http://dx.doi.org/10.1016/j.mrrev.2006.06.001 
[30] Modgil, M., Mahajan, K. and Chakrabarti, S.K. (2004) Molecular Analysis of Genetic Stability in Micropropagated Apple Rootstock MM106. Scientia Horticulturae, 104, 151-160. http://dx.doi.org/10.1016/j.scienta.2004.07.009

[31] Livak, K.J. and Schmittgen, T.D. (2001) Analysis of Relative Gene Expression Data Using Real-Time Quantitative PCR and the $2^{-\Delta \Delta C T}$ Method. Methods, 25, 402-408. http://dx.doi.org/10.1006/meth.2001.1262

[32] Trucco, F., Jeschke, M.R., Rayburn, A.L. and Tranel, P.J. (2005) Promiscuity in Weedy Amaranths: High Frequency of Female Tall Waterhemp (Amaranthus tuberculatus) $\times$ Smooth Pigweed (A. hybridus) Hybridization under Field Conditions. Weed Science, 53, 46-54. http://dx.doi.org/10.1614/WS-04-103R

[33] Teaster, N.D. and Hoagland, R.E. (2013) Varying Tolerance to Glyphosate in a Population of Palmer Amaranth with Low EPSPS Copy Number. American Journal of Plant Sciences, 4, 2408-2013. http://dx.doi.org/10.4236/ajps.2013.412297

[34] Franssen, A.S., Skinner, D.Z., Al-Khatib, K., Horak, M.J. and Kulakow, P.A. (2001) Interspecies Hybridization and Gene Flow of ALS Resistance in Amaranthus Species. Weed Science, 49, 598-606. http://dx.doi.org/10.1614/0043-1745(2001)049[0598:IHAGFO]2.0.CO;2

[35] Gaines, T.A., Shaner, D.L., Ward, S.M., Leach, J.E. and Westra, P. (2011) Mechanism of Resistance of Evolved Glyphosate-Resistant Palmer Amaranth (Amaranthus palmeri). Journal of Agriculture and Food Chemistry, 59, 58865889. http://dx.doi.org/10.1021/jf104719k

[36] Zoghlami, N., Bouamama, B., Khammassi, M. and Ghorbel, A. (2012) Genetic Stability of Long-Term Micropropagated Opuntia ficus-indica (L.) Mill. Plantlets as Assessed by Molecular Tools: Perspectives for In Vitro Conservation. Industrial Crops and Products, 39, 59-64. http://dx.doi.org/10.1021/jf104719k

[37] Panda, M.K., Mohanty, M., Subudhi, E., Acharya, L. and Nayak, S. (2007) Assessment of Genetic Stability of Micropropagated Plants of Curcuma longa L. by Cytophotometry and RAPD Analyses. International Journal of Integrative Biology, 1, 189-195.

[38] Rani, V., Parida, A. and Raina, S.N. (1995) Random Amplified DNA (RAPD) Markers for Genetic Analysis in Micropropagated Plants of Populus deltoids Marsh. Plant Cell Reports, 14, 459-462. http://dx.doi.org/10.1007/BF00234055

[39] Gesteira, S., Otoni, W.C., Barros, E.G. and Moreira, M.A. (2002) RAPD-Based Detection of Genomic Instability in Soybean Plants Derived from Somatic Embryogenesis. Plant Breeding, 121, 269-271. http://dx.doi.org/10.1007/BF00234055

[40] Ray, T. and Roy, S.C.(2009) Genetic Diversity of Amaranthus Species from Indo-Gangetic Plains Revealed by RAPD Analysis Leading to the Development of Ecotype-Specific SCAR Marker. Journal of Heredity, 100, 338-347. http://dx.doi.org/10.1093/jhered/esn102

[41] Gaines, T.A., Wright, A.A., Molin, W.T., Lorentz, L., Riggins, C.W., Tranel, P.J., Beffa, R., Westra, P. and Powles, S.B. (2013) Identification of Genetic Elements Associated with EPSPS Gene Amplification. PLoS ONE, 8, e65819. http://dx.doi.org/10.1371/journal.pone.0065819

[42] Sammons, R.D. and Gaines, T. (2014) Glyphosate Resistance: State of Knowledge. Pest Management Science, 70, 1367-1377.

[43] Rani, V. and Raina, S.N. (2000) Genetic Fidelity of Organized Meristem-Derived Micropropagated Plants: A Critical Reappraisal. In Vitro Cellular \& Developmental Biology-Plant, 36, 319-330. http://dx.doi.org/10.1007/s11627-000-0059-6 
Scientific Research Publishing (SCIRP) is one of the largest Open Access journal publishers. It is currently publishing more than 200 open access, online, peer-reviewed journals covering a wide range of academic disciplines. SCIRP serves the worldwide academic communities and contributes to the progress and application of science with its publication.

Other selected journals from SCIRP are listed as below. Submit your manuscript to us via either submit@scirp.org or Online Submission Portal.
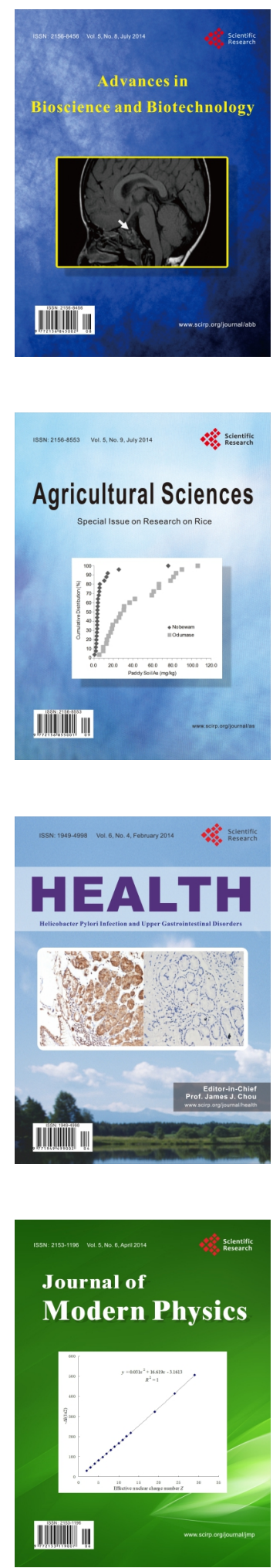
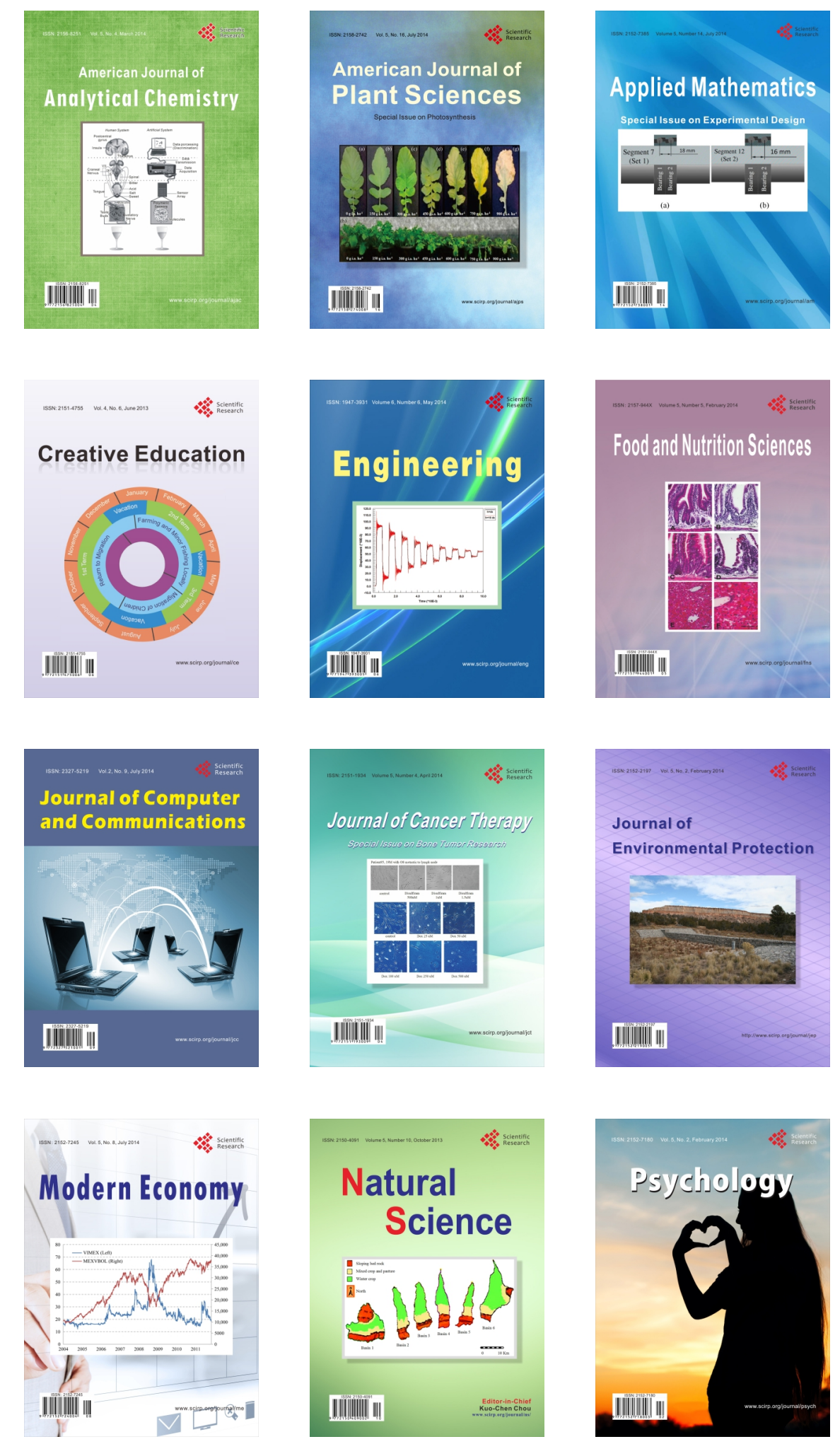